\title{
FAKTOR-FAKTOR YANG MEMPENGARUHI KINERJA PENYULUH PERTANIAN DALAM PENINGKATAN PRODUKTIVITAS KAKAO DI KOTA PALOPO
}

\author{
Sapar $^{1}$, Lanteng Butami ${ }^{2}$ \\ Sekolah Tinggi Ilmu Ekonomi Muhammadiyah Palopo \\ E_Mail: sapar@stiem.ac.id
}

\begin{abstract}
Abstrak: Tujuan jangka panjang penelitian ini adalah peningkatan kemampuan petani dalam berusahatani kakao sehingga berdampak pada peningkatan produktivitas kakao sehingga para petani kakao semakin sejahtera secara ekonomi, sosial dan budaya. Kinerja penyuluh pertanian yang baik berdampak pada perbaikan kinerja petani dalam memproduksi kakao. Kinerja penyuluh ini terarah pada pemecahan masalah yang dihadapi oleh petani dalam melaksanakan usahatani kakao. Target khusus yang ingin dicapai dalampenelitian ini adalah: diketahuinya faktor-faktoryang memengaruhi kinerja penyuluh pertanian kakao dalampeningkatan produktivitas kakao di Kota Palopo sehingga berdampak pada peningkatan kemampuan petani kakao dalam berusahatani kakao. Unit analisis penelitian adalah penyuluh pertanian yang populasinya adalah 111 orang penyuluh pertanian. Berdasarkan rumus Slovin dengan tingkat kesalahan lima persen, diperoleh sampel berjumlah 87 orang penyuluh pertanian. Sampel diambil secara proporsional random sampling dari Telluwanua (14 orang), Bara (9 orang), Wara Utara (10 orang), Wara (11 orang), Wara Barat (9 orang), Wara Timur(9 orang) Wara Selatan (9 orang), Mungkajang ( 7 orang) dan Sendana (9 orang). Metode yang digunakan dalam penelitian ini adalah metode survey, dengan menjadikan angket sebagai bahan utama mengumpulkan data. Data yang dikumpulkan kemudian dianalisis menggunakan Regresi Berganda dengan program SPSS 21.0 Hasil penelitian ini menunjukkan bahwa umur berpengaruh -0,018 terhadap kinerja penyuluh, pendidikan formal berpengaruh -0,032, pelatihan teknis 0,061, pengalaman kerja 0,111, lokasi tugas -0,756, luas wilayah kerja-0,012, jumlah petani binaan -0,082 dan interaksi dengan petani 0.045 terhadap kinerja penyuluh pertanian kakao. Simpulan penelitian ini adalah umur, pendidikan formal, pelatihan teknis, pengalaman kerja, luas wilayah kerja, jumlah petani binaan dan interaksi dengan petani binaan secara statistik tidak berpengaruh terhadap kinerja penyuluh pertanian sedangkan lokasi tugas berpengaruh terhadap kinerja penyuluh pertanian, karena itu disarankan kepada atasan penyuluh pertanian kakao untuk memperhatikan faktor-faktor tersebut khususnya lokasi tugas penyuluh.
\end{abstract}

Kata kunci: Kinerja, Penyuluh Pertanian, usahatani kakao

\section{PENDAHULUAN}

Kinerja penyuluh pertanian ditentukan pada pencapaian tujuan yang ditetapkan oleh organisasi penyuluhan pertanian dengan batasan waktu yang telah ditentukan. Kinerja penyuluh pertanian didasarkan pada tugas pokok dan fungsinya yang diuraikan secara komprehensif pada uraian macam-macam tugas. Kinerja penyuluh pertanian dilihat pada aspek persiapan, pelaksanaan, evaluasi dan pelaporan, pengembangan penyuluhan pertanian dan pengembangan profesi penyuluh pertanian. Aspek berikutnya adalah kepemimpinan, komunikasi, kemitraan usaha dan diseminasi teknologi serta penguasaan terhadap bidang teknis keahlian.

Kinerja penyuluh pertanian pada aspek persiapan, pelaksanaan, evaluasi dan pelaporan merupakan rangkaian sistematis dan terstruktur dalam alur tak terpisahkan. Programa penyuluhan pertanian berlandaskan pada analisis kebutuhan petani dan kondisi khalayak sasaran saat ini serta kondisi khalayak sasaran yang akan diwujudkan. Programa penyuluhan pertanian adalah proses pembelajaran antara petani dengan penyuluh yang dimulai dengan proses sharing informasi dan keterlibatan aktif petani pada perencanaan yaitu 
mengidentifikasi potensi wilayah, agroekosistem dan kebutuhan teknologi.

Aspek berikutnya adalah materi dan metode yang dipilih dalam melakukan penyuluhan pertanian. Materi dan metode adalah substansi dalam penyuluhan yang dikondisikan pada kebutuhan petani. Tujuan akhir penyuluhan pertanian ditentukan oleh materi dan metode yang dilakukan penyuluh pertanian. Materi adalah objekyang disuluhkan sedangkan metode adalah cara menyampaikan objek tersebut.

Parameter berikutnya adalah pelaporan dan evaluasi penyuluhan. Pelaporan dan evaluasi dikategorikan dalam dua aspek yaitu pelaporan dari hasil penyuluhan dan evaluasi dampak penyuluhan pertanian. Pelaporan dan evaluasi sebagai introspeksi diri penyuluh pertanian tentang target yang belum dicapai dan perlu diperbaiki.

Aspek berikutnya adalah pengembangan penyuluhan pertanian dan profesi penyuluh. Penyuluh mempelajari pedoman dan petunjuk pelaksanaan penyuluhan pertanian serta metode atau sistem kerja penyuluhan pertanian. Penyuluh pertanian menambah input berupa pengetahuan ilmu-ilmu penyuluhan terkini melalui pelatihan dan seminar, membuat karya tulis atau karya ilmiah dan membeli buku-buku penyuluhan.

Penyuluh yang berhasil adalah penyuluh yang mampu merancang dan melaksanakan program pembelajaran, materi dan metodenya sesuai dengan kondisi dan karakteristik petani. Penyuluh pertanian harus mampu pada aspek kepemimpinan, komunikasi, diseminasi teknologi dan bidang teknis yang akan disuluhkan.

Akhirnya disimpulkan bahwa persiapan, pelaksanaan, evaluasi dan pelaporan, pengembangan penyuluhan dan profesi penyuluh, kepemimpinan, komunikasi, kemitraan usaha, diseminasi teknologi serta penguasaan bidang teknis keahlian merupakan kegiatan pokok yang dilakukan penyuluh pertanian dan parameter mengukur kinerja seorang penyuluh pertanian

\section{METODE DAN BAHAN}

Penelitian ini dilaksanakan di Kantor Balai Penyuluhan Pembangunan (BPP) dan Badan Ketahanan Pangan dan Penyuluhan Pertanian (BKPPP) Kota Palopo dari bulan Maret sampai Juni 2016. Unit analisis penelitian adalah penyuluh pertanian yang populasinya adalah 111 orang penyuluh pertanian. Berdasarkan rumus Slovin dengan tingkat kesalahan lima persen, diperoleh sampel berjumlah 87 orang penyuluh pertanian. Sampel diambil secara proporsional random sampling dari Telluwanua (14 orang), Bara (9 orang), Wara Utara (10 orang), Wara (11 orang), Wara Barat (9 orang), Wara Timur (9 orang) Wara Selatan (9 orang), Mungkajang (7 orang) dan Sendana ( 9 orang).

Penelitian menggunakan metode survei melalui pengisian kuesioner yang didukung wawancara. Validitas instrumen yang digunakan adalah validitas isi (content validity) yang dikonsultasikan kepada lima orang pakar. Hasil perbaikan instrumen ini diujicobakan kepada 15 penyuluh pertanian. Dengan menggunakan uji Cronbach Alpha diperoleh koefisien reliabilitas masing-masing sebesar 0,812, yang instrumen tersebut reliabel. Data yang dikumpulkan kemudian dianalisis menggunakan Regresi Berganda dengan program SPSS 21.0 


\section{HASIL DAN PEMBAHASAN}

Model hipotetik yang diajukan berasal dari satu peubah bebas dan delapan peubah terikat. Setelah dilakukan pendugaan peubah yang berpengaruh pada kinerja penyuluh pertanian, ditemukan model struktural kinerja penyuluh pertanian yang menunjukkan jalur pengaruh antar peubah. Dari model pada Gambar 1, dirumuskan persamaan model struktural kinerja pertanian sebagai berikut :

$\mathrm{Y}=\mathrm{a}-0,018 \mathrm{X} 1-0,032 \mathrm{X} 2+0,061 \mathrm{X} 3-0,111 \mathrm{X} 4$ $-0,0756$ X5 - 0,012 X6 - 0,082 X7 + 0,045X8

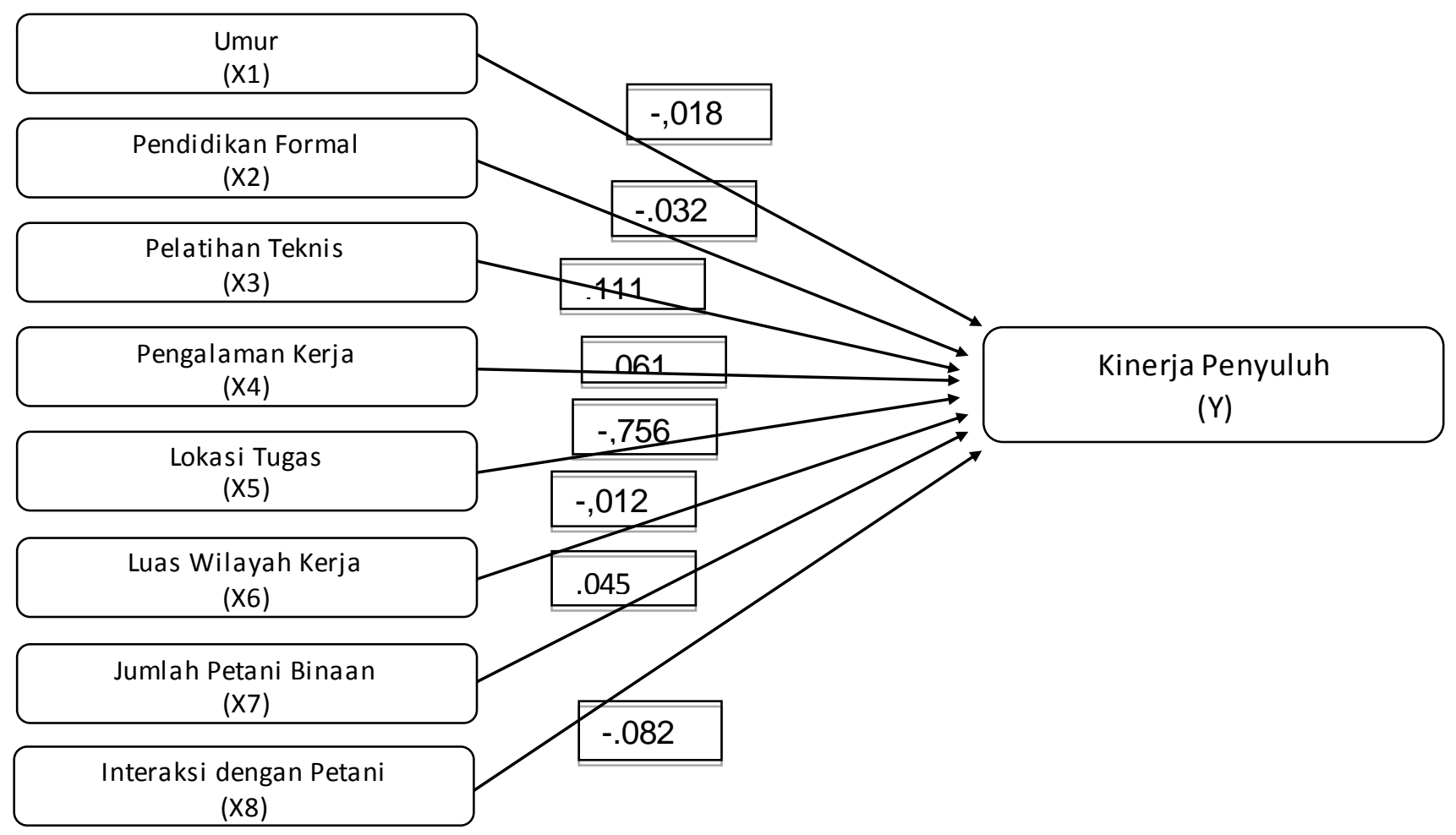

Gambar. Model struktural Faktor-Faktor yang Memengaruhi Kinerja Penyuluh pertanian Kakao di Kota Palopo

\section{Pengaruh Umur terhadap Kinerja Penyuluh Pertanian Kakao}

Hasil analisis secara parsial dapat disimpulkan bahwa umur berpengaruh negatif terhadap kinerja penyuluh pertanian kakao. Hal ini dibuktikan dengan uji secara parsial diperoleh koefisien regresi untuk variabel umur bernilai negatif $(-0,017)$ yang berarti bahwa setiap peningkatan umur akan mempengaruhi penurunan kinerja penyuluh pertanian kakao. Sedangkan untuk uji $\mathrm{t}$ diperoleh nilai $\mathrm{t}$ hitung sebesar $-0,232$ lebih kecil dari nilai $\mathrm{t}$ tabel yaitu 1,991 dan signifikansi sebesar 0,817 lebih besar dari 0,05 maka dapat disimpulkan bahwa variabel umur tidak berpengaruh signifikan terhadap kinerja penyuluh pertanian kakao. 
Hasil penelitian ini sejalan dengan peneltian yang dilakukan oleh Raharjo (2012) yang meyatakan bahwa usia tidak mempunyai pengaruh yang signifikan terhadap kinerja penyuluh pertanian yang ada di Kabupaten Boyolali.

Hal tersebut diperkuat dengan pendapat Padmowihardjo (2004), yang menyatakan bahwa umur seseorang diduga kuat memengaruhi kemampuannya, baik kemampuan fisik ataupun kemampuan berpikir (inteligensia). Semakin tua umur seseorang akan semakin berkurang atau menurun kemampuannya, karena itu umur erat kaitannya dengan kinerjai seseorang.

\section{Pengaruh Pendidikan Formal te rhadap Kinerja Penyuluh Pertanian Kakao}

Hasil analisis secara parsial dapat disimpulkan bahwa pendidikan formal berpengaruh negatif terhadap kinerja penyuluh pertanian kakao. Hal ini dibuktikan dengan uji secara parsial diperoleh koefisien regresi untuk variabel pendidikan formal bernilai negatif (0,066 ) yang berarti bahwa setiap peningkatan pendidikan formal akan mempengaruhi penurunan kinerja penyuluh pertanian kakao. Sedangkan untuk uji $\mathrm{t}$ diperoleh nilai t hitung sebesar -0,439 lebih kecil dari nilai $\mathrm{t}$ tabel yaitu 1,991 dan signifikansi sebesar 0.662 lebih besar dari 0,05 maka dapat disimpulkan bahwa variabel pendidikan formal tidak berpengaruh signifkan terhadap kinerja penyuluh pertanian kakao.

Hasil penelitian ini sejalan dengan peneltian yang dilakukan oleh Raharjo (2012) yang meyatakan bahwa tidak terdapat pengaruh yang signifikan antara pendidikan terhadap kinerja penyuluh pertanian di yang ada di Kabupaten Boyolalai. Hasil penelitian ini dikarenakan tidak terdapat perbedaan penilaian kinerja antara penyuluh yang ada di Kabupaten Boyolali dengan latar belakang pendidikan yang berbeda. Sedangkan dari hasil penelitian ini dapat diketahui bahwa sebagian besar penyuluh mempunyai pendidikan S1 dengan latar belakang pendidikan pertanian. Sehingga perbedaan tingkat pendidikan yang ada pada penyuluh tidak menunjukkan perbedaan kinerja yang ada pada penyuluh pertanian yang ada di Kabupaten Boyolali.

\section{Pengaruh Pelatihan terhadap Kinerja Penyuluh Pertanian Kakao}

Hasil analisis secara parsial dapat disimpulkan bahwa pelatihan berpengaruh positif terhadap kinerja penyuluh pertanian kakao. Hal ini dibuktikan dengan uji secara parsial diperoleh koefisien regresi untuk variabel pelatihan bernilai negatif $(0,162)$ yang berarti bahwa setiap peningkatan pelatihan akan mempengaruhi peningkatan kinerja penyuluh pertanian kakao. Sedangkan untuk uji $\mathrm{t}$ diperoleh nilai $\mathrm{t}$ hitung sebesar 0,798 lebih kecil dari nilai t tabel yaitu 1,991 dan signifikansi sebesar 0,427 lebih besar dari 0,05 maka dapat disimpulkan bahwa variabel pelatihan tidak berpengaruh signifkan terhadap kinerja penyuluh pertanian kakao.

Hasil penelitian ini tidak sejalan dengan peneltian yang dilakukan oleh Celestino Goncalves Talo Mali (2012) yang menunjukkan bahwa variabel pelatihan dan sikap penyuluh pertanian lapangan berpengaruh positif dan signifikan terhadap kinerja penyuluh pertanian lapangan.

Lebih lanjut Simanjuntak

mendefinisikan bahwa pelatihan merupakan bagian dari investasi sumber daya manusia (human investment) untuk meningkatkan kemampuan dan keterampilan kerja, dan dengan demikian 
meningkatkan produktivitas kerja pegawai. Tujuan dari pelatihan adalah untuk mengembangkan kompetensi atau keterampilan (skills) pegawai khususnya yang mendukung tugas dan pekerjaan pegawai pada posisi yang sedang dipangkunya. Oleh karena itu, pelatihan yang dilakukan harus sesuai dengan kebutuhan pegawai dan diberikan dalam waktu yang relatif pendek guna untuk membekali seorang pegawai dengan keterampilan kerja.

\section{Pengaruh Masa Kerja terhadap Kinerja Penyuluh Pertanian Kakao}

Hasil analisis secara parsial dapat disimpulkan bahwa masa kerja berpengaruh positif terhadap kinerja penyuluh pertanian kakao. Hal ini dibuktikan dengan uji secara parsial diperoleh koefisien regresi untuk variabel pelatihan bernilai positif $(0,096)$ yang berarti bahwa setiap peningkatan masa kerja akan mempengaruhi peningkatan kinerja penyuluh pertanian kakao. Sedangkan untuk uji $\mathrm{t}$ diperoleh nilai $\mathrm{t}$ hitung sebesar 1,403 lebih kecil dari nilai t tabel yaitu 1,991 dan signifikansi sebesar 0,165 lebih besar dari 0,05 maka dapat disimpulkan bahwa variabel masa kerja tidak berpengaruh signifkan terhadap kinerja penyuluh pertanian kakao.

Hasil penelitian di atas tidak sejalan dengan pendapat Heidjrachman (2002:69), yang mengatakan bahwa kecakapan akan selalu meningkat dengan meningkatnya pengalaman kerja sehingga semakin berpengalaman seorang karyawan maka kemampuan untuk menyelesaikan tugas-tugas yang diberikan oleh perusahaan maka akan semakin cepat terselesaikan dengan baik. Oleh karena itu seorang karyawan yang banyak pengalaman kerja ia akan mudah menyelesaikan tugas/pekerjaannya dibandingkan dengan seorang karyawan yang kurang berpengalaman, sehingga tujuan organisasi atau perusahaan akan tercapai atau tidak sangat tergantung kepada kemahiran kerja karyawan yang berpengalaman itu.

\section{Pengaruh Lokasi Kerja terhadap Kinerja Penyuluh Pertanian Kakao}

Hasil analisis secara parsial dapat disimpulkan bahwa lokasi kerja berpengaruh negatif terhadap kinerja penyuluh pertanian kakao. Hal ini dibuktikan dengan uji secara parsial diperoleh koefisien regresi untuk variabel pelatihan bernilai negatif $(-0,808)$ yang berarti bahwa setiap peningkatan lokasi kerja akan mempengaruhi penurunan kinerja penyuluh pertanian kakao. Sedangkan untuk uji t diperoleh nilai t hitung sebesar -10,239 lebih kecil dari nilai t tabel yaitu -1,991 dan signifikansi sebesar 0,000 lebih besar dari 0,05 maka dapat disimpulkan bahwa variabel lokasi kerja berpengaruh signifkan terhadap kinerja penyuluh pertanian kakao.

Hasil penelitian di atas sejalan dengan pendapat Rudy Lantang Janis (2013), yang mengatakan bahwa Penyuluh akan maksimal bekerja ketika beban kerja sesuai dengan kemampuan dan kapasitas penyuluh itu sendiri, ketika seorang penyuluh harus menangani beberapa pekerjaan sekaligus, atau menangani wilayah binaan yang lebih dari satu pasti akan merasa sulit untuk memaksimalkan pekerjaannya. Sulit membagi waktu dan tidak fokus pada tugas pokoknya sebagai penyuluh. Kinerja seorang penyuluh dengan satu wilayah bianaan/dampingan akan berbeda dengan kinerja penyuluh dengan wilayah binaan lebih dari 1. Penyuluh yang memiliki wilayah binaan yang lebih dari satu atau memiliki tugas rangkap di kantor akan sulit membagi waktu untuk mendampingi petani dalam 
usahanya, apalagi untuk penyuluh yang berdomisili di luar wilayah binaan.

Pengaruh Luas Wilayah terhadap Kinerja Penyuluh Pertanian Kakao

Hasil analisis secara parsial dapat disimpulkan bahwa luas wilayah berpengaruh negatif terhadap kinerja penyuluh pertanian kakao. Hal ini dibuktikan dengan uji secara parsial diperoleh koefisien regresi untuk variabel luas wilayah bernilai positif $(-0,002)$ yang berarti bahwa setiap peningkatan luas wilayah akan mempengaruhi penurunan kinerja penyuluh pertanian kakao. Sedangkan untuk uji t diperoleh nilai t hitung sebesar -0.151 lebih kecil dari nilai $t$ tabel yaitu 1,991 dan signifikansi sebesar 0.880 lebih besar dari 0,05 maka dapat disimpulkan bahwa variabel luas wilayah tidak berpengaruh signifkan terhadap kinerja penyuluh pertanian kakao.

Hasil penelitian di atas sejalan dengan pendapat Rudy Lantang Janis (2013) yang menyatakan bahwa semakin luas wilayah kerja penyuluh pertanian, semakin sulit dan terbatas baginya untuk melakukan kegiatan penyuluhan. Waktu tempuh yang diperlukan untuk melakukan kegiatan dari satu tempat ke tempat lain akan semakin lama dan membutuhkan biaya operasional semakin tinggi. Petani membutuhkan informasi maupun kehadiran penyuluh pertanian tidak dapat segera terwujud. Mereka harus menunggu dan hal tersebut dapat membuat petani jenuh dan frustasi. Dengan demikian, luas wilayah kerja penyuluh akan berpengaruh pada kompetensi mereka.

Pengaruh Jumlah Petani Binaan terhadap Kine rja Penyuluh Pertanian Kakao

Hasil analisis secara parsial dapat disimpulkan bahwa jumlah petani binaan berpengaruh negatif terhadap kinerja penyuluh pertanian kakao. Hal ini dibuktikan dengan uji secara parsial diperoleh koefisien regresi untuk variabel jumlah petani binaan bernilai negatif (0,082) yang berarti bahwa setiap peningkatan jumlah petani binaan akan mempengaruhi peningkatan kinerja penyuluh pertanian kakao. Sedangkan untuk uji $\mathrm{t}$ diperoleh nilai $\mathrm{t}$ hitung sebesar -1,088 lebih kecil dari nilai t tabel yaitu 1,991 dan signifikansi sebesar 0,280 lebih besar dari 0,05 maka dapat disimpulkan bahwa variabel jumlah petani binaan tidak berpengaruh signifkan terhadap kinerja penyuluh pertanian kakao.

Hasil Penelitian ini sejalan dengan penelitian yang dilakukan oleh Lubis RA (2014) yang menyatakan bahwa jumlah petani binaan tidak berpengaruh signifikan terhadap kinerja penyuluh pertanian kakao. Hal ini disebabkan karena dengan semakin banyaknya jumlah petani yang dibina akan membuat penyuluh kewalahan dalam memberikan materi penyuluhan secara efektif dan efisien.

\section{Pengaruh Interaksi terhadap Petani Binaan terhadap Kine rja Penyuluh Pertanian Kakao}

Hasil analisis secara parsial dapat disimpulkan bahwa interaksi terhadap petani binaan berpengaruh positif terhadap kinerja penyuluh pertanian kakao. Hal ini dibuktikan dengan uji secara parsial diperoleh koefisien regresi untuk variabel interaksi terhadap petani binaan bernilai negatif $(-0,045)$ yang berarti bahwa setiap peningkatan jumlah petani binaan akan mempengaruhi penurunan kinerja penyuluh pertanian kakao. Sedangkan untuk uji t diperoleh nilai $\mathrm{t}$ hitung sebesar 0,593 lebih kecil dari nilai $\mathrm{t}$ tabel yaitu 1,991 dan signifikansi sebesar 0,555 lebih besar dari 0,05 maka dapat disimpulkan 
bahwa variabel jumlah petani binaan tidak berpengaruh signifkan terhadap kinerja penyuluh pertanian kakao.

\section{DAFTAR PUSTAKA}

Hasil penelitian ini sejalan dengan penelitian Pera Nurfathiyah (2015) yang menyatakan Interaksi partisipatif penyuluh pertanian secara langsung berpengaruh pada kinerja penyuluh pertanian. Setiap peningkatan satu satuan interaksi partisipatif penyuluh pertanian, akan meningkatkan kinerja mereka sebesar 0,40 satuan

\section{SIMPULAN}

Berdasarkan hasil analisis dan pembahasan, maka dapat dirumuskan kesimpulan sebagai berikut (a) umur tidak berpengaruh terhadap kinerja penyuluh pertanian kakao, (b) pendidikan formal tidak berpengaruh terhadap kinerja penyuluh pertanian kakao, (c) pelatihan teknis tidak berpengaruh terhadap kinerja penyuluh pertanian kakao, (d) pengalaman kerja tidak berpengaruh terhadap kinerja penyuluh pertanian kakao, (e) lokasi tugas berpengaruh terhadap kinerja penyuluh pertanian kakao, (f) luas wilayah kerja tidak berpengaruh terhadap terhadap kinerja penyuluh pertanian kakao, (g) jumlah petani binaan tidak berpengaruh terhadap kinerja penyuluh pertanian kakao, dan (h) interaksi dengan petani tidak berpengaruh terhadap kinerja penyuluh pertanian kakao, sehingga disarankan Pemerintah Kota Palopo Cq. Badan Ketahanan Pangan dan Penyuluhan Pertanian agar memperhatikan faktor-faktor yang memengaruhi kinerja penyuluh terutama faktor lokasi tugas.

\section{Buku}

Atmosoeprapto K. 2008. Menuju SDM Berdaya: Dengan Kepemimpinan Efektif dan Manajemen Efisien. Jakarta: PT Alex Media Komputindo, Kelompok Gramedia.

Armansyah 2007. Growth Need Strength sebagai Moderator Hubungan antara Karakteristik Pekerjaan dengan Kepuasan Kerja Secara Umum. Jakarta: Universitas Indonesia.

Rosyada A. 2009. Paradigma Pendidikan Gratis, Sebuah Model Pelibatan Masyarakat dalam Penyelenggaraan Pendidikan. Jakarta: Prenada Media Indonesia.

Sapar. 2010. Faktor-Faktor yang Memengaruhi Kinerja Penyuluh Pertanian dan Dampaknya pada Kompetensi Petani Kakao di Empat Wilayah Sulawesi Sekatan. Bogor: Makaira Printing Plus

Saydam G. 2007. Built in Training. Jakarta: Rosda.

Wibowo. 2007. Manajemen Kinerja. Jakarta: Raja Grafindo Persada.

Zainun B. 2009. Administrasi dan Manajemen Kepegawaian. Jakarta: Haji Mas Agung

\section{Jurnal, Artikel, Laporan Hasil Penelitian dan Prosiding}

Bestina S, Slamet H, Amiruddin S. 2010. Kinerja Penyuluh Pertanian dalam Pengembangan Agribisnis Nenas di Kecamatan Tambang, Kabupaten Kampar. Laporan Hasil Penelitian. Kendari: Balai Pengkajian Teknologi Pertanian Kendari.

Lasmahadi, A. 2002. Sistem Manajemen Sumberdaya Manusia Berbasis Kompetensi. http $/ /$ www.sdm.go.id. Diakses 2 Pebruari 2011

Sapar. 2011. "Faktor-Faktor yang Berpengaruh pada Kinerja Penyuluh Pertanian dan Dampaknya pada Kompetensi Petani Kakao 
di Empat Wilayah Sulawesi Selatan."J.

Forum Pascasarjana, Vol 34 No. 4 hal: 297-305 